\title{
Evidence of denitrification and nitrate ammonification in the River Rhone plume (northwestern Mediterranean Sea)
}

\author{
Patrick Omnes, Gerd Slawyk, Nicole Garcia, Patricia Bonin* \\ Centre d'Océanologie de Marseille, Laboratoire d'Oceanologie et de Biogeochimie, OSU, CNRS, URA41, \\ Campus de Luminy, Case 901, F-13288 Marseille Cedex 9, France
}

\begin{abstract}
Water samples were collected from the turbid plume water of the River Rhone at 2 stations (near the river mouth and at the plume front) between November and June 1993. The 2 dissimilatory pathways of nitrate reduction, denitrification and nitrate ammonification, were measured using a combination of the acetylene inhibition and ${ }^{15} \mathrm{~N}$ techniques. Irrespective of the sampling site, denitrification and nitrate ammonification rates, measured without nitrate and glucose amendment, ranged

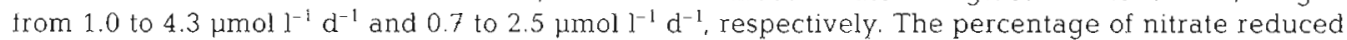
to ammonium varied between 12 and $33 \%$ of the total nitrate dissimilated. Both processes occurred simultaneously and competed for nitrate as an electron acceptor The reduction of nitrate to ammonium was inhibited by oxygen, indicating that the mechanism of reduction was dissimilatory. The dissimilatory character of nitrate ammonification was unequivocally confirmed in experiments using a bacterial community isolated from a natural water sample
\end{abstract}

KEY WORDS: Nitrate ammonification Denitrification ${ }^{15} \mathrm{~N}$. Water column Mediterranean Sea

\section{INTRODUCTION}

The use of inorganic fertilizers has considerably increased the concentration of nitrate carried by rivers. The River Rhone constitutes an important source of freshwater (between 500 and $5000 \mathrm{~m}^{3} \mathrm{~s}^{-1}$ ) and the runoff contribution to the nitrogen budget is clearly of major importance for an oligotrophic sea such as the Mediterranean. The nitrogen input from the River Rhone consists principally of nitrate (55000 $\left.\mathrm{yr}^{-1}\right)$, and is considered to be the most eutrophicating telluric nutrient supply to the northwestern Mediterranean Sea (Leveau \& Coste 1987)

In the surface water of the River Rhone plume corresponding to the nepheloid water, in situ nitrate concentrations differed by 10 to $30 \mu \mathrm{M}$ from the theoretical values (conservative dilution), showing that this compound is partly consumed as a consequence of bacterial nitrate reduction (Bianchi et al. 1994). Bianchi et al. (1994) demonstrated that denitrification occurs

\footnotetext{
- Addressee for correspondence.

E-mail: pbonin@com.univ-mrs.fr
}

in highly turbid estuarine waters with a high nitrate concentration; particulate organic matter provides microniches that allow anaerobic processes to occur in an oxygenated water column.

In anaerobic ecosystems, denitrification is considered as the most important of the nitrate reduction processes. Buresh \& Patrick (1981) observed greater reduction of nitrate to ammonium in the presence of glucose and further suggested that reduction occurred via a dissimilatory pathway in which nitrate served as an electron acceptor. Furthermore, dissimilatory nitrate reduction to ammonium can occur under the conditions required for denitrification (Hattori 1983), and this dissimilatory pathway conserves nitrogen in a useful form which may then be assimilated by microorganisms in environments where nitrogen is the limiting nutrient.

The occurrence of this process has been demonstrated in marine sediments (Koike \& Hattori 1978, Sorensen 1978); but, to our knowledge, this pathway has never been quantified in the water column. In the present study we investigated the capacity of surface waters of the River Rhone plume to denitrify and reduce nitrate to ammonium. The significance of dissimi- 
latory nitrate reduction to ammonium varies from one ecosystem to another, thus in the soil the process is of minor importance whereas in marine sediments dissimilatory nitrate reduction to ammonium is a major process (Tiedje et al. 1982). The second objective of this study was to compare the potential for nitrate ammonification with the denitrification potential of sea water

\section{MATERIALS AND METHODS}

Sampling area. During 3 cruises (between November 1993 and June 1993), water samples were collected in an area extending from north of the River Rhone towards the open sea. Stn $1\left(43^{\circ} 18^{\prime} \mathrm{N}, 04^{\circ} 50^{\prime} \mathrm{E}\right)$ was representative of hydrological conditions near the mouth of the River Rhone, i.e. high surface current (Rhone jet), high turbidity, high nitrate concentration whereas $\operatorname{Stn} 4\left(43^{\circ} 19^{\prime} \mathrm{N}, 04^{\circ} 52^{\prime} \mathrm{E}\right.$, February; $43^{\circ} 18^{\prime} \mathrm{N}$ $04^{\circ} 52^{\prime} \mathrm{E}$, June; $43^{\circ} 17^{\prime} \mathrm{N}, 04^{\circ} 53^{\prime} \mathrm{E}$, November) was representative of the mobile frontal envelope which marks the boundary between the 2 water masses (the water of the River Rhone and the sea water). The plume front is characterized by a marked change in the colour of the water and by a line of foam.

Chemical analysis. Water samples were collected at $0.5 \mathrm{~m}$ depth using sterile polycarbonate bottles. Salinity, temperature and oxygen concentration were measured with an Orbisphere probe (2606, Orbisphere Laboratories, Geneva, Switzerland). Subsamples were used for measurements of ammonium (Solorzano 1969), nitrite (Bendschneider \& Robinson 1952) and nitrate by Technicon 'Autoanalyzer' (Tréguer \& Le Corre 1975).

Microbial counts. Total bacterial counts were performed by an image analysis system on cells stained by DAPI (Porter \& Feig 1980). Total phytoplankton counts were performed according to Lund et al. (1958).

Microbial activities. A combination of the acetylene inhibition technique to assay for denitrification and a ${ }^{15} \mathrm{~N}$ isotope tracer technique to measure dissimilatory nitrate reduction was performed. Determinations of the bacterial activities were performed in $100 \mathrm{ml}$ subsamples kept in $130 \mathrm{ml}$ serum flasks. These subsamples were inoculated with ${ }^{15} \mathrm{NO}_{3}$ (97.4 atom\%, Isotec Matheson, USA); the amount of ${ }^{15} \mathrm{NO}_{3}{ }^{-}$added was less than $10 \%$ of the in situ concentration. An $\mathrm{NH}_{4} \mathrm{Cl}$ solution $(100 \mu l)$ corresponding to a final concentration of about $1 \mathrm{mM}$ was added to repress the nitrate assimilation pathway (Tiedje 1988). Flasks were sealed with butyl rubber stoppers and anaerobic conditions were obtained by flushing with oxygen free $\mathrm{N}_{2}$ for 5 min. Acetylene $(15 \mathrm{kPa})$, which inhibits the reduction from $\mathrm{N}_{2} \mathrm{O}$ to $\mathrm{N}_{2}$, was added to the flasks (Balderston et al. 1976, Yoshinari et al. 1977). The incubations were stopped by adding $100 \mu \mathrm{l}$ of $\mathrm{HgCl}_{2}(1 \mathrm{mM})$. Nitrate, nitrite and nitrous oxide analyses were performed at time zero (starting time of incubation) and after 1, 3, 5 and $24 \mathrm{~h}$ incubation in the dark at temperatures corresponding to the in situ values $\left( \pm 1^{\circ} \mathrm{C}\right)$. Simultaneously, ${ }^{15} \mathrm{~N} /{ }^{14} \mathrm{~N}$ isotopic compositions of $\mathrm{NH}_{4}{ }^{+}$and particulate organic matter (POM) were determined.

Denitrifying activity. The initial linear rate of nitrous oxide accumulation is considered as a measure of the denitrification activity. $\mathrm{N}_{2} \mathrm{O}$ assays were performed following short-term incubations; $\mathrm{N}_{2} \mathrm{O}$ concentrations were measured at various times during the incubation period to establish linearity. The normal incubation period was $3 \mathrm{~h}$. After incubation, a $2.5 \mathrm{ml}$ sample of the gas phase was removed into a pre-evacuated Venoject tube. Extraction of nitrous oxide from the liquid phase was carried out by the procedure of Chan \& Knowles (1979) modified by the technique of multiple equilibrium (McAulife 1971). Nitrous oxide was determined using a Girdel series 30 gas chromatograph equipped with an electron capture detector as described by Bonin et al. (1987)

Nitrate ammonifying activity. The major criterion that permits the identification of dissimilatory nitrate reduction to ammonium is the production of ammonium from nitrate in the presence of an excess of reduced nitrogen that is needed for growth. According to Tiedje et al.'s (1.989) procedure, we determined the rates of nitrate ammonifying activity by measuring ${ }^{15} \mathrm{NH}_{4}{ }^{+}$plus organic ${ }^{15} \mathrm{~N}$ production from ${ }^{15} \mathrm{NO}_{3}{ }^{-}$in the presence of an excess of ammonium ( $1 \mathrm{mM}$ ) to repress nitrate assimilating pathways. The progressive increase in isotopic enrichment of the ammonium and particulate fractions was monitored with time as the substrate $\left(\mathrm{NO}_{3}{ }^{-}\right)$was used. Ammonium was removed from the solution by microdiffusion at $60^{\circ} \mathrm{C}$. The samples were treated with a mild alkali ( $\mathrm{MgO}$ ) to convert $\mathrm{NH}_{4}{ }^{+}$to $\mathrm{NH}_{3}$, which was trapped on acidified $(50 \mu \mathrm{l}, 0.5 \mathrm{~N}$ $\mathrm{H}_{2} \mathrm{SO}_{4}$ ) pre-combusted Whatman GF/C filters (Brooks et al. 1989) The ammonium removal efficiency was greater than $98 \%$. Since the amount of nitrogen present in the samples was below the sensitivity of the mass spectrometer, a known quantity $(1 \mu \mathrm{mol})$ of unlabelled ammonium (carrier nitrogen) was added immediately after extraction. The amount of carrier nitrogen added was taken into account when calculating the ammonium production rates. POM was collected by differential filtration (pre-combusted Whatman GF/D filter, porosity $2.7 \mu \mathrm{m}$, and GF/F filter, porosity $0.7 \mu \mathrm{m}$ ). In order to avoid damage of cells during filtration, samples were gently filtered using low vacuum ( $<100 \mathrm{~mm} \mathrm{Hg}$ ) To eliminate the remaining dissolved forms of nitrogen, each filter was washed with $1 \mathrm{ml}$ of ammonium free synthetic sea water When $100 \mathrm{ml}$ of plume water was filtered through a $25 \mathrm{~mm}$ diameter GF/D filter, we observed that (1) all the phytoplankton cells were 
retained on the GF/D filter (no large phytoplankton cell was deposited on the GF/F filter) and (2) for natural bacterial densities in the range of $1-5 x$ $10^{6}$ bacteria $\mathrm{ml}^{-1}$, only about $30 \%$ and $45 \%$ of the cells were retained on GF/D and GF/F filters, respectively. Both filters ( $\mathrm{NH}_{4}{ }^{+}$and POM) were analyzed for ${ }^{15} \mathrm{~N}$ content by mass spectrometry (Tracer mass, European Scientific, Crewe, UK).

The precision of both rate measurements, calculated from 5 replicates. was almost identical with a coefficient of variation $(\mathrm{CV}=\mathrm{SD} \times 100 / \bar{x})$ of $15.3 \%$ and $22.5 \%$ for denitrification and nitrate ammonification, respectively.

Experimental study. The growth medium was prepared by adding Bacto-peptone $\left(0.29 \mathrm{~g} \mathrm{l}^{-1}\right)$, glucose $\left(0.32 \mathrm{~g} \mathrm{l}^{-1}\right)$, sodium acetate $\left(0.53 \mathrm{~g} \mathrm{l}^{-1}\right)$; $\mathrm{NH}_{4} \mathrm{Cl}(0.19 \mathrm{~g}$ $\left.\mathrm{l}^{-1}\right)$ and $\mathrm{KNO}_{3}\left(0.11 \mathrm{~g} \mathrm{l}^{-1}\right)$ as an electron acceptor to filter sterilized water $(0.2 \mu \mathrm{m})$ collected from Stn 1 . The inoculum was obtained from the same water sample, sonicated (Branson 2200) to break up microbial aggregates and to remove bacteria from their mineral or organic support, and filtered through an $0.8 \mu \mathrm{m}$ pore size filter. To initiate growth, $100 \mathrm{ml}$ of inoculum was used. Cultures were incubated under aerobic or anaerobic conditions in 1.21 serum flasks containing 1 l of the above medium enriched with $110 \mu \mathrm{mol}$ of ${ }^{15} \mathrm{NO}_{3}$ $(97.4$ atom $\%)$. Anaerobic conditions were obtained by flushing nitrogen through the flask. Aerobic conditions were maintained by bubbling air through a fritted disk in the medium during the experiment.

The bacterial counts for monitoring growth and the microbial activities were determined as described for natural samples.

\section{RESULTS AND DISCUSSION}

Data presented in Table 1 show the in situ physicochemical characteristics of Stns 1 and 4 on a seasonal basis. Temperature reflected seasonal variations from February to December 1993. For both stations, salinity remained constant whatever the sampling time, indicating that the river discharge was approximately constant. Oxygen was close to saturation level in the water. Nitrate was the most abundant form of dissolved inorganic nitrogen $190 \%$ of the total). These results were similar to those reported by Leveau et al. (1990) In situ nitrate concentrations were between 17 and $30 \mu \mathrm{M}$ lower than those estimated from conservative dilution, showing a net consumption of this compound, as previously observed by Bianchi et al. (1994).

\section{Denitrifying and nitrate ammonifying activities}

This study was carried out on water samples collected during 3 cruises (1993) in the surface water of the River Rhone corresponding to the nepheloid layer.

The denitrifying and nitrate ammonifying activities measured on sea-water samples incubated anaerobically without nitrogen or carbon source amendment are presented in Fig. 1. Under these experimental conditions, denitrification rates ranged from 1.0 to $4.3 \mu \mathrm{mol} \mathrm{I}^{-1} \mathrm{~d}^{-1}$, independent of the sampling site, although nitrate concentrations were higher at Stn 1 near the river mouth. In the water samples collected from the plume nepheloid, denitrifying activities were in the same range as those previously reported by Bianchi et al. (1994) for the northwestern Mediterranean Sea and were similar to those recorded in the Baltic (Shaffer \& Rönner 1984, Rönner \& Sorenson 1985).

During 2 out of 3 cruises, ammonium production was observed in samples collected at both stations incubated anaerobically without nitrogen and carbon amendments. Activities ranged from 0.4 to $1.8 \mu \mathrm{mol} \mathrm{l^{-1 }}$ $\mathrm{d}^{-1}$ (Fig. 1). The rates of ${ }^{15} \mathrm{NH}_{4}{ }^{+}$incorporation into the organic fraction $\mathrm{N}$ are reported in Table 2. Although the number of bacteria retained on GF/D filters was lower than on GF/F filters, the rate of organic ${ }^{15} \mathrm{~N}$ production was higher on GF/D filters. Under these conditions, we cannot exclude uptake by phytoplankton of ammonium derived from the nitrate ammonification pathway, despite unfavorable incubation conditions (increased ammonium concentration, darkness and absence of oxygen) that should repress this process. Indeed, Anderson \& Kristensen (1988) have reported that phytoplankton (diatoms) may continue to assimilate nitrogen for $2 \mathrm{~d}$ after their last photoperiod. Thus, to measure the true nitrate ammonification rate, only ${ }^{15} \mathrm{~N}$-POM collected on GF/F filters was taken into account. The incorporation of ${ }^{15} \mathrm{NH}_{4}{ }^{+}$into ${ }^{15} \mathrm{~N}$-POM 
a
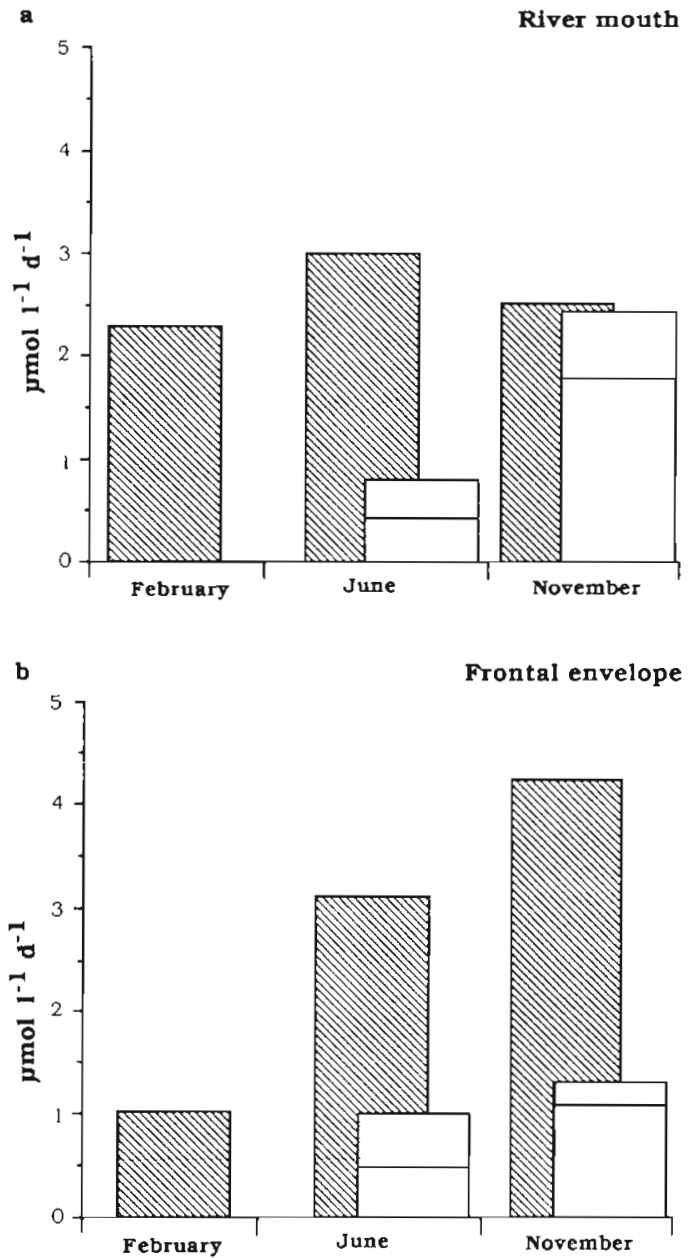

Fig. 1 Rates of denitrification (S) and dissimilatory nitrate reduction to ammonium (ammonium production $\square$ and its incorporation into particulate organic matter $\square$ ) in the River Rhone plume. Water samples were collected during 3 cruses in February, June and November 1.993 at 2 sampling stations:

(a) $\operatorname{Stn} 1$ (river mouth) and (b) $\operatorname{Stn} 4$ (frontal envelope)

corrected for bacteria collected on the GF/F filters (see 'Materials and methods'). The sum of the rate of ammonium accumulation plus its incorporation into bacterial POM ranged from 0.7 to $2.5 \mu \mathrm{mol} \mathrm{l}^{-1} \mathrm{~d}^{-1}$ (Fig 1).

The amount of nitrate transformed to ammonium plus the amount incorporated into the POM accounted for between 12 and $33 \%$ of the total dissimilatory nitrate consumption (nitrate recovered as nitrous oxide plus ammonium). Despite the various procedures used to measure both pathways in marine sediments, Koike \& Hattori (1978) reported that 20 to $70 \%$ of the added $\mathrm{NO}_{3}{ }^{-}$was converted to ammonia and particulate organic nitrogen, whereas Sorensen (1978) demonstrated that the capacity for $\mathrm{NO}_{3}{ }^{-}$reduction to $\mathrm{NH}_{4}{ }^{+}$ in marine sediments was of the same magnitude as denitrification.
Table 2. Ammonium incorporation ( $\mu$ mol $~^{-1} \mathrm{~d}^{-1}$ ) in particulate organic matter (POM) collected on GF/D and GF/F filters at Stns 1 (river mouth) and 4 (frontal envelope) during 2 cruises in June and November 1993

\begin{tabular}{|c|c|c|c|c|}
\hline & \multicolumn{2}{|c|}{ June } & \multicolumn{2}{|c|}{ November } \\
\hline & Stn 1 & Stn 4 & Stn 1 & Stn 4 \\
\hline${ }^{15} \mathrm{~N}-\mathrm{POM}(\mathrm{GF} / \mathrm{D})$ & 0.90 & 0.30 & 0.39 & 0.18 \\
\hline${ }^{15} \mathrm{~N}-\mathrm{POM}(\mathrm{GF} / \mathrm{F})$ & 0.15 & 0.22 & 0.30 & 0.10 \\
\hline${ }^{15} \mathrm{~N}-\mathrm{POM}$ corrected ${ }^{\mathrm{a}}$ & 0.33 & 0.49 & 0.67 & 0.22 \\
\hline \multicolumn{5}{|c|}{${ }^{15} \mathrm{~N}-\mathrm{POM}$ corrected $={ }^{15} \mathrm{~N}-\mathrm{POM}(\mathrm{GF} / \mathrm{F}) \times(100 / 45)$} \\
\hline
\end{tabular}

The study of the effect of temperature on these activities was undertaken. Small variations in temperature at the sites studied $\left(<10^{\circ} \mathrm{C}\right)$ do not allow observation of the effect of temperature on in situ bacterial activities (Fig. 1). However, when the incubation temperature was increased from $19^{\circ} \mathrm{C}$ (in situ temperature) to $29^{\circ} \mathrm{C}$, the denitrification rate was 1.5 -fold higher; no effect of the incubation temperature on nitrate ammonification was observed (Fig. 2). Most of the studies about the effect of temperature on denitrification have been carried out with soil samples. The exposure of soil samples to temperatures ranging from 10 to $35^{\circ} \mathrm{C}$ gives $Q_{10}$ values in the range 1.5 to 3 (Knowles 1982). With regard to the aquatic sediments, different results have been reported. Andersen (1977) reported very little vanation in activity with temperature. In contrast, for a change of temperature of about $20^{\circ} \mathrm{C}$, Jorgensen (1989) observed 2 maxima for denitrification capacity (June and December) with a predominance of nitrate ammonification between the 2 denitrification maxima.

The initial activities of functional enzymes (denitrifying and nitrate ammonifying) were measured under saturating concentrations of electron donors and

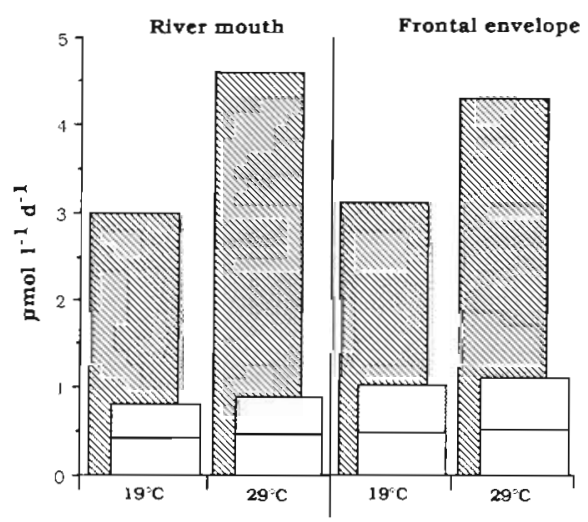

Fig. 2. Effect of incubation temperature on denitrification (N) and nitrate ammonification (ammonium production $\square$ and its incorporation into particulate organic matter $\square$ ) in samples collected at Stns 1 (river mouth) and 4 (frontal envelope) in June 1993 
acceptors. We added glucose $(1 \mathrm{mM})$ and nitrate $(1 \mathrm{mM})$ and chloramphenicol $\left(1 \mathrm{~g} \mathrm{l}^{-1}\right)$, as suggested by Tiedje et al. (1989), to determine denitrifying enzyme activities (DEA). Chloramphenicol inhibits protein synthesis, thus extending the period of linear $\mathrm{NH}_{4}{ }^{+}$or $\mathrm{N}_{2} \mathrm{O}$ accumulation. In this study, ammonifying activities were determined simultaneously with DEA according to Tiedje et al.'s procedure. Unexpectedly, and in contrast to activities generally observed in sediment samples, the DEA measured in amended water samples showed equal or lower values than denitrifying activities determined in unamended samples (Fig. 3). In the River Rhone plume, the in situ nitrate and carbon contents are high and thus probably are not limiting factors. In contrast, the rate of nitrate ammonification increased when glucose and nitrate were added. Therefore, the experimental conditions recommended by Tiedje (1988) may favor nitrate ammonification when both routes of dissimilatory nitrate reduction are present. Moreover, in natural conditions as well as in experimental conditions nitrate ammonifying bacteria could outcompete denitrifiers.

Nitrate ammonification is now widely recognized as a process distinct from assimilatory nitrate reduction. Although the product of both pathways is ammonium, their regulation is different. The product of the dissimilatory pathway is regulated by oxygen and is unaffected by ammonium, while the converse is observed with assimilatory reduction. During the November cruise, nitrate ammonification was determined after anaerobic or aerobic incubations without nitrate and glucose amendments. Ammonium production and its incorporation into the bacterial nitrogen pool were substantially affected by oxygen (Fig. 4a). The reference level of both activities was determined under anaerobic conditions. After aerobic incubation, the

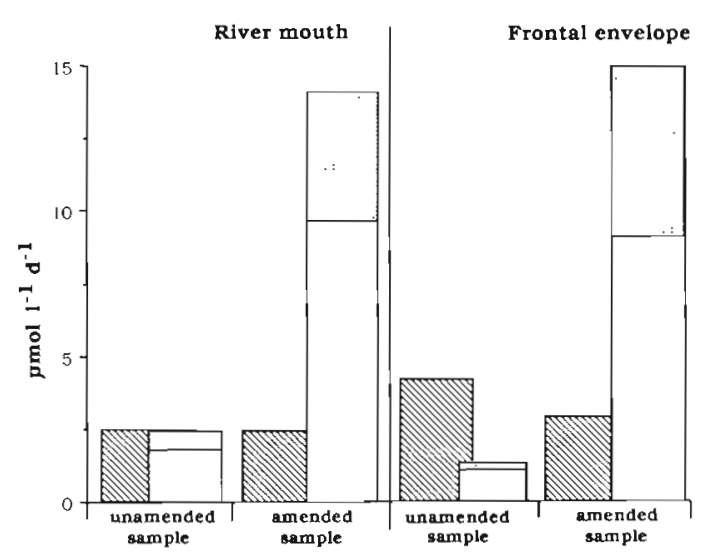

Fig. 3. Rates of denitrification (\$) and nitrate ammonification (ammonium production $\square$ and its incorporation into particulate organic matter $\square$ ) determined without (unamended sample) and after nitrate $(1 \mathrm{mM})$ and glucose $(1 \mathrm{mM})$ amendments (amended sample)
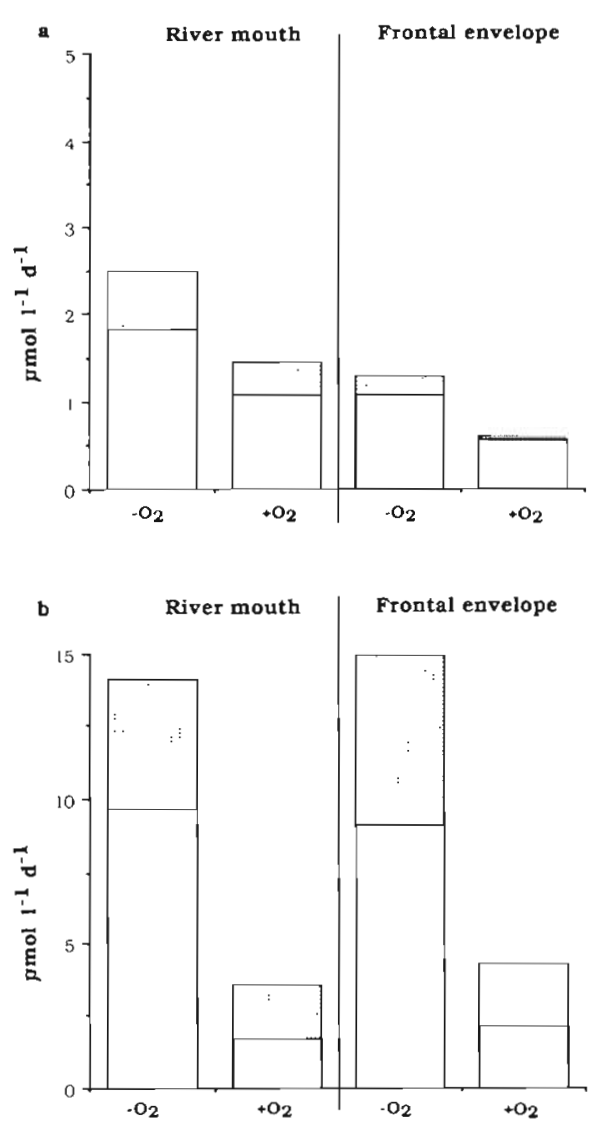

Fig. 4. Effect of oxygen on nitrate ammonification (ammonium production $\square$ and its incorporation into organic matter $\square$ ) determined (b) with and (a) without nitrate (1 $\mathrm{mM})$ and glucose (1 $\mathrm{mM})$ amendments

rates of ammonium production and incorporation ranged from 18 to $59 \%$ and 18 to $38 \%$ of the reference levels, respectively. A similar effect was observed when samples were incubated with and without nitrate and glucose amendments (Fig. $4 \mathrm{~b}$ ). The incomplete inhibition of nitrate ammonification by oxygen shows (1) the dissimilatory nature of the measured activity and (2) the occurrence of this process in oxygenated water samples. The presence of anoxic microniches within the particulate material may support nitrate ammonification in oxic environments (Bianchi et al. 1994).

\section{Experimental study}

In the second part of our investigation, in order to confirm that bacterial dissimilatory nitrate reduction to ammonium occurs in natural water samples within particulate suspended matter, the experiments were repeated with a natural bacterial community. ${ }^{15} \mathrm{~N}$ measurements were made during aerobic and anaerobic growth conditions (Fig. 5). Under anaerobic conditions 

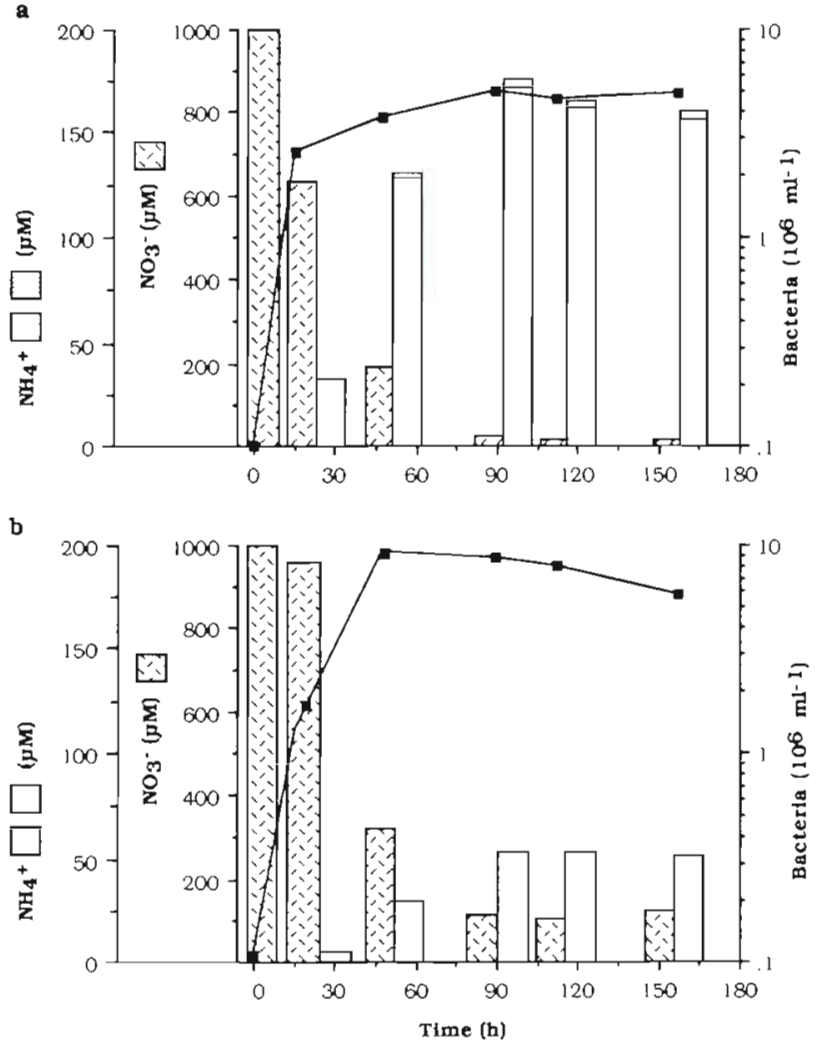

Fig. 5. Nitrate consumed ( $)$, ammonium produced ( $\square$ ) and its incorporation into cell material ( $\square$ ) during (a) anaerobic and

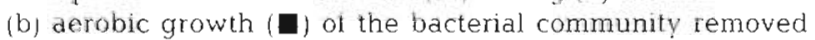
from suspended particulate matter

(Fig. 5a), $\mathrm{NO}_{3}{ }^{-}$was consumed during the initial phase of growth. After $120 \mathrm{~h}$ of incubation nitrate concentration decreased from $1 \mathrm{mM}$ to $14 \mu \mathrm{M}$. The majority of the nitrate reduced accumulated as nitrite until the end of the exponential phase of growth (15 h), with a maximal nitrite concentration of $450 \mu \mathrm{M}$ (data not shown). Production of ${ }^{15} \mathrm{~N}$-labelled $\mathrm{NH}_{4}{ }^{+}$commenced at the end of the log phase of growth and reached a maximal concentration of $170 \mu \mathrm{M}$ after $90 \mathrm{~h}$. After $50 \mathrm{~h}$, a proportion of ${ }^{15} \mathrm{NO}_{3}{ }^{-}$reduced to ${ }^{15} \mathrm{NH}_{4}{ }^{+}$was assimilated into cell biomass. Approximately $5 \mu \mathrm{M}$ of the produced $\mathrm{NH}_{4}{ }^{+}$ was incorporated into cell material. These results were consistent with data obtained with pure cultures of Citrobacter sp. (Smith 1982), Pseudomonas putrefaciens (Samuelson 1985), and Enterobacter amnigenus (Fazzolari et al. 1990). Under aerobic conditions (Fig. 5b) ammonium production was approximately $20 \%$ of that produced under anderobic conditions. Incorporation into organic matter was undetectable. These experiments clearly demonstrate the presence of bacteria able to perform the $\mathrm{NO}_{3}$ dissimilation to $\mathrm{NH}_{4}{ }^{+}$in the River Rhone plume.

In conclusion, this study has demonstrated the potential for denitrification and nitrate ammonification in the River Rhone plume. The percentage of nitrate transformed to ammonium varied between 12 and $33 \%$ of the total nitrate dissimilated. The presence of bacteria able to perform this process was also demonstrated. Nitrate ammonification was repressed by oxygen, providing evidence for the dissimilatory rather than assimilatory nature of the reduction process. Both processes occur simultaneously and compete for $\mathrm{NO}_{3}$ as an electron acceptor Denitrification causes a nitrogen loss, whereas reduction of $\mathrm{NO}_{3}^{-}$to $\mathrm{NH}_{4}^{+}$is particularly interesting for the ecosystem because it conserves nitrogen as ammonium.

Acknowledgements. We are grateful to Dr A. Bianchi for critical comments on the manuscript. We also thank D. Raphel for skilled technical assistance.

\section{LITERATURE CITII)}

Anderson FO, Kristensen E (1988) The influence of macrofauna on estuarine benthic community metabolism: a microcosm study. Mar Biol 99:591-603

Andersen JM (1977) Rates of denitrification of undisturbed sediment from six lakes as a function of nitrate concentratıon, oxygen and temperature. Arch Microbiol 80:147-159

Balderston WL, Sherr B, Payne WJ (1976) Blockage by acetylene of nitrous oxide production in Pseudomonas portectomarinus. Appl Environ Microbiol 31:504-508

Bendschneider K, Robinson RJ (1952) A new spectrophotometric method for the determination of nitrite in seawater. J Mar Res 11:87-96

Bianchi M, Bonin P, Feliatra (1994) Bacterial nitrification and denitrification rates in the Rhone river plume (northwestern Mediterranean Sea). Mar Ecol Prog Ser 103:197-202

Bonin P, Gilewicz M, Bertrand JC (1987) Denitrification by a marine bacterium Pseudomonas nautica strain 617. Ann Inst Pasteur Microbiol 138:371-383

Brooks PD, Stark JM, McInteer B 3, Preston T (1989) Diffusion method to prepare soil extracts for automated nitrogen-15 analysis. Soil Sci Soc Am J 53:1707-1711

Buresh RJ, Patrick WH (1981) Nitrate reduction to ammonium and organic nitrogen in an estuarine sediment. Soil Biol Biochem 13:279-283

Chan YK, Knowles R (1979) Measurement of denitrification in two freshwater sediments by an in situ acetylene inhibition method. Appl Environ Microbiol 37:1067-1072

Fazzolari E, Mariotti A, Germon JC (1990) Nitrate reduction to ammonia: a dissimilatory process in Enterobacter amnigenus. Can J Microbiol 36:779-785

Hattori A (1983) Denitrification and dissimilatory nitrate reduction. In: Carpenter EJ, Capone DG (eds) Nitrogen in the marine environment. Academic Press, New York, p $191-232$

Jorgensen KS (1989) Annual. pattern of denitrification and nitrate ammonification in estuarine sediment. Appl Environ Microbiol 55:1841-1847

Knowles R (1982) Denitrification. Microbiol Rev 46:43-70

Koike I, Hatton A (1978) Denitrification and ammonia formation in anaerobic coastal sediments. Appl Environ Microbiol 35:278-282

Leveau M, Coste B (1987) Impacts des apports rhodaniens sur les milieux pélagiques du Golfe du Lion. Bull Ecol 18: $119-122$ 
Leveau M, Lochet F, Goutx M, Blanc F (1990) Effects of a plume front on the distribution of inorganic and organic matter of the Rhône River. Hydrobiologia 207:87-93

Lund JWG, Kipling C, Le Cren ED (1958) The inverted microscope method of estimating algal numbers and the statistical basis of estimations by counting. Hydrobiologia 11. $143-170$

McAulife L (1971) GC determination of solutes by multiple phase equilibration. Chem Technol 1:46-51

Porter KG, Feig YS (1980) The use of DAPl for identifying and counting aquatic microflora. Limnol Oceanogr 29:943-948

Rönner U, Sörenson F (1985) Denitrification rates in low oxygen water of the stratified Baltic Proper. Appl Environ Microbiol 50:801-806

Samuelson MO (1985) Dissimilatory nitrate reduction to nitrite, nitrous oxide and ammonium by Pseudomonas putrefaciens. Appl Environ Microbiol 50:812-815

Shaffer G, Rönner U (1984) Denitrification in the Baltic proper deep water. Deep Sea Res 31:197-220

Smith MS (1982) Dissimilatory reduction of $\mathrm{NO}_{2}{ }^{-}$to $\mathrm{NH}_{4}{ }^{+}$and $\mathrm{N}_{2} \mathrm{O}$ by a soil Citrobacter sp. Appl Environ Microbiol 43 $854-860$

Solorzano L (1969) Determination of ammonium in natural

This article was presented by A. Bianchi, Marseille, France waters by the phenol hypochlorite method. Limnol Oceanogr 14:799-801

Sorensen J (1978) Capacity for denitrification and reduction of nitrate to ammonia in a coastal marine sediment. Appl Environ Microbiol 35:301-305

Tiedje JM (1988) Ecology of denitrification and dissimilatory nitrate reduction to ammonium. In: Zehnder AJB (ed) Biology of anaerobic microorganisms. John Wiley and Sons Press, New York, p 179-244

Tiedje JM, Sexstone AJ, Myrold DD, Robinson JA (1982) Denitrification: ecological niches, competition and survival. Antonie van Leeuwenhoek 48:569-583

Tiedje JM, Simkins S, Groffman PM (1989) Perspectives on measurement of denitrification in the field including recommended protocols for acetylene based methods. Plants Soil 115:261-284

Tréguer P, Le Corre P (1975) Manuel d'analyse des sels nutritifs dans l'eau de mer (utilisation de l'AutoAnalyzer II Technicon). Laboratoire d'Océanographie Chimique, Université de Bretagne Occidentale, Brest, p 110

Yoshinari T, Hynes R, Knowles R (1977) Acetylene inhibition of nitrous oxide reduction and measurement of denitrification and nitrogen fixation in soil. Soil Biol Biochem 9:177-183

Manuscript first received: February 26, 1995

Revised version accepted: January 30, 1996 